\title{
Cell death in Leishmania
}

Louise Basmaciyan $^{1}$, and Magali Casanova ${ }^{2, *}$

${ }^{1}$ UMR PAM A, Valmis Team, 2 rue Angélique Ducoudray, BP 37013, 21070 Dijon Cedex, France

2 Aix-Marseille University, CNRS, LISM, Institut de Microbiologie de la Méditerranée, 13402 Marseille Cedex 09, France

Received 16 July 2019, Accepted 26 November 2019, Published online 11 December 2019

\begin{abstract}
Leishmaniases still represent a global scourge and new therapeutic tools are necessary to replace the current expensive, difficult to administer treatments that induce numerous adverse effects and for which resistance is increasingly worrying. In this context, the particularly original organization of the Leishmania parasite in comparison to higher eukaryotes is a great advantage. It allows for the development of new, very specific, and thus non-cytotoxic treatments. Among these originalities, Leishmania cell death can be cited. Despite a classic pattern of apoptosis, key mammalian apoptotic proteins are not present in Leishmania, such as caspases, cell death receptors, and anti-apoptotic molecules. Recent studies have helped to develop a better understanding of parasite cell death, identifying new proteins or even new apoptotic pathways. This review provides an overview of the current knowledge on Leishmania cell death, describing its physiological roles and its phenotype, and discusses the involvement of various proteins: endonuclease G, metacaspase, aquaporin Li-BH3AQP, calpains, cysteine proteinase C, LmjHYD36 and Lmj.22.0600. From these data, potential apoptotic pathways are suggested. This review also offers tools to identify new Leishmania cell death effectors. Lastly, different approaches to use this knowledge for the development of new therapeutic tools are suggested: either inhibition of Leishmania cell death or activation of cell death for instance by treating cells with proteins or peptides involved in parasite death fused to a cell permeant peptide or encapsulated into a lipidic vector to target intra-macrophagic Leishmania cells.
\end{abstract}

Key words: Leishmania, Cell death, Phenotype, Role, Pathways.

Résumé - La mort cellulaire chez Leishmania. Alors que les leishmanioses représentent toujours un fléau mondial, de nouveaux outils thérapeutiques sont nécessaires pour remplacer les traitements actuels qui sont chers, difficiles à administrer, qui induisent de nombreux effets secondaires et pour lesquels la résistance est de plus en plus inquiétante. Pour cela, l'organisation très originale du parasite Leishmania par rapport aux eucaryotes supérieurs est un grand avantage. En effet, cela permet le développement de nouveaux traitements très spécifiques et donc non cytotoxiques. Parmi ces originalités, la mort cellulaire de Leishmania peut être citée. Malgré un aspect classique d'apoptose, les protéines apoptotiques clefs des mammifères ne sont pas présentes chez Leishmania, telles que les caspases, les récepteurs de mort et les molécules anti-apoptotiques. Des études récentes ont participé à une meilleure compréhension de la mort cellulaire du parasite, identifiant de nouvelles protéines ou même de nouvelles voies apoptotiques. Cette revue fait le point sur l'état actuel des connaissances sur la mort cellulaire de Leishmania, décrivant ses rôles physiologiques et son phénotype et discutant l'implication de différentes protéines : endonucléase G, métacaspase, aquaporine Li-BH3AQP, calpaïnes, cystéine protéinase C, LmjHYD36 et Lmj.22.0600. À partir de ces données, différentes voies apoptotiques potentielles sont suggérées. Cette revue fournit également des outils pour identifier de nouveaux effecteurs de la mort cellulaire de Leishmania. Pour finir, différentes approches pour utiliser ces connaissances pour le développement de nouveaux outils thérapeutiques sont suggérées : soit inhibition de la mort cellulaire de Leishmania, soit activation de celle-ci par exemple en traitant les cellules avec des protéines/peptides impliqués dans la mort du parasite fusionnés à un peptide pénétrant dans les cellules ou encapsulés dans un vecteur lipidique pour cibler les cellules de Leishmania intra-macrophagiques.

\begin{tabular}{llll} 
Abbreviations & MCA & Metacaspase \\
\multicolumn{1}{l}{} & & PCD & Programmed Cell Death \\
ACD & Accidental Cell Death & PI & Propidium Iodide \\
CALP & CAlpain-Like Proteins & RCD & Regulated Cell Death \\
CPC & Cysteine Proteinase C & SKCRP & Small Kinetoplastid Calpain-Related Proteins \\
\end{tabular}

*Corresponding author: magali. casanova@univ-amu.fr

This is an Open Access article distributed under the terms of the Creative Commons Attribution License (https://creativecommons.org/licenses/by/4.0), which permits unrestricted use, distribution, and reproduction in any medium, provided the original work is properly cited. 


\section{Introduction: Leishmania parasites}

Parasites of the Leishmania genus, which are responsible for leishmaniases, are flagellated protozoa of the Trypanosomatidae family like Trypanosoma brucei, the causal agent of human African trypanosomiasis, and T. cruzi, the agent of Chagas disease. Leishmaniases are considered by the World Health Organization (WHO) to be a neglected tropical disease, mainly affecting low-income people worldwide. Between 700,000 and 1 million infections are estimated worldwide, causing between 20,000 and 30,000 deaths per year (Global Health Observatory data from WHO, 2018). In 2017, $94 \%$ of the new cases reported to the WHO occurred in seven countries: Brazil, Ethiopia, India, Kenya, Somalia, South Sudan and Sudan (WHO reports). Three main types of leishmaniasis are described: cutaneous, mucocutaneous and visceral leishmaniasis, also known as kala-azar. Leishmaniases are a major health problem because of the absence of satisfactory treatments, the adverse effects of treatments, their cost, their mode of administration which is mostly parenteral, limiting their use in developing countries, and the emergence of drug-resistant strains.

Leishmania parasites are transmitted to mammals by the bite of a female sand fly. In the digestive tract of the vector, parasites proliferate as mobile flagellated parasites called promastigotes: procyclic promastigotes within the midgut and virulent metacyclic promastigotes in the insect proboscis $[9,20]$. After inoculation to the mammalian host, promastigotes are taken up by phagocytic cells where they transform into an immobile form with a reduced flagellum called the amastigote form.

\section{Cell death in general}

Contrary to what one might think, the limit between life and death is not so clear. To overcome this, the Nomenclature Committee on Cell Death proposed, in 2015, to consider a cell to be dead if (i) the cell has lost its plasma membrane integrity, or if (ii) the cell, including the nucleus, has undergone complete fragmentation into what is usually termed "apoptotic bodies", or if (iii) cell fragments have been phagocytized by a nearby cell in vivo [40]. Currently, two main types of cell death are described: Accidental Cell Death (ACD) and Regulated Cell Death (RCD) [28]. ACD is induced by harsh physical, chemical or mechanical damage such as, for example, high temperatures, high pressure, potent detergents, extreme $\mathrm{pH}$ variations or shearing [28]. This type of cell death is virtually immediate and does not involve specific molecular machinery [28]. As a consequence, no genetic construction and no specific drug can be used to activate or inhibit ACD. On the contrary, RCD involves molecular machinery that is genetically encoded, allowing genetic and pharmacologic manipulations to alter this type of cell death [28]. RCD appears in two circumstances: (i) when the cell is facing micro-environmental disruptions, and (ii) during embryonic development, tissue homeostasis and immune responses; this physiological type of RCD being termed Programmed Cell Death (PCD) [28].

The terms necrosis, apoptosis and autophagy are classically described based on cell morphology. Necrosis is morphologically characterized by a gain in cell volume, organelle swelling, loss of plasma membrane integrity and, as a consequence, loss of intracellular contents [41]. For a long time, necrosis was considered a form of accidental non-controlled cell death, inducing ACD. However, it is now described as a potential RCD inducer since it can be finely regulated owing to specific signal transduction pathways [41].

The term "apoptosis", coined by Kerr et al. [39], is, by definition, a type of cell death that is characterized by several morphological features among which cell rounding, retraction of pseudopods, cell shrinkage, chromatin condensation, nuclear fragmentation, few ultrastructural modifications of cytoplasmic organelles, plasma membrane modifications with maintenance of its integrity, membrane blebbing that culminates in the formation of apoptotic bodies and, in vivo, phagocytosis by nearby cells [40]. Apoptosis induces RCD and it is often wrongly confused with PCD which is, as previously said, a physiological form of RCD that occurs in the context of embryo development and tissue homeostasis [30]. Classically, apoptosis is described as being initiated by intracellular or extracellular stimuli, involving the intrinsic or extrinsic apoptosis pathway respectively, two signal transduction pathways that are interconnected. The intrinsic pathway involves pro- and antiapoptotic molecules of the Bcl-2 family and relies on mitochondrial outer membrane permeabilization that results in the release of molecules from mitochondria, such as cytochrome c, and, in fine, to the activation of specific enzymes called caspases [26]. The extrinsic pathway involves cell death receptors inserted in the plasma membrane as well as caspases and molecules of the Bcl-2 family [12]. It should be noted that this view of the apoptotic signal transduction pathways is simplistic. In fact, the term "apoptosis" hides high biochemical, functional and immunological diversity. Several apoptotic subtypes, while morphologically similar, can be induced by different biochemical pathways and may result in different consequences, for instance concerning recognition by the immune system [41]. In the same way, while ACD consistently presents a necrotic morphology (cell disintegration by loss of plasma membrane integrity), RCD can present a wide range of morphologies and can result from different signal transduction pathways, including regulated necrosis and apoptosis [15]. To define these different types of RCD, based on their biochemical and molecular characterization, many terms have been introduced, such as, for instance, extrinsic or intrinsic apoptosis, mitochondrial permeability transition-driven necrosis, necroptosis, ferroptosis or pyroptosis [29].

Concerning macro-autophagy, here confused with autophagy, it is a cell survival process that allows the cell to survive nutrient or growth factor deprivation [45]. More precisely, it is an intracellular catabolic process that sequesters cytosol and organelles in double-membrane vesicles called autophagosomes for fusion with and degradation into lysosomes [45]. Amino acids generated are recycled and used for protein synthesis. Some authors have introduced the term "autophagic cell death". However, as clearly defined by the Nomenclature Committee on Cell Death, it does not correspond to a type of cell death that is induced by autophagy but a type of cell death with autophagy, that is to say where autophagosomes appear [30]. As a consequence, autophagic cell death is a form of cell death that 


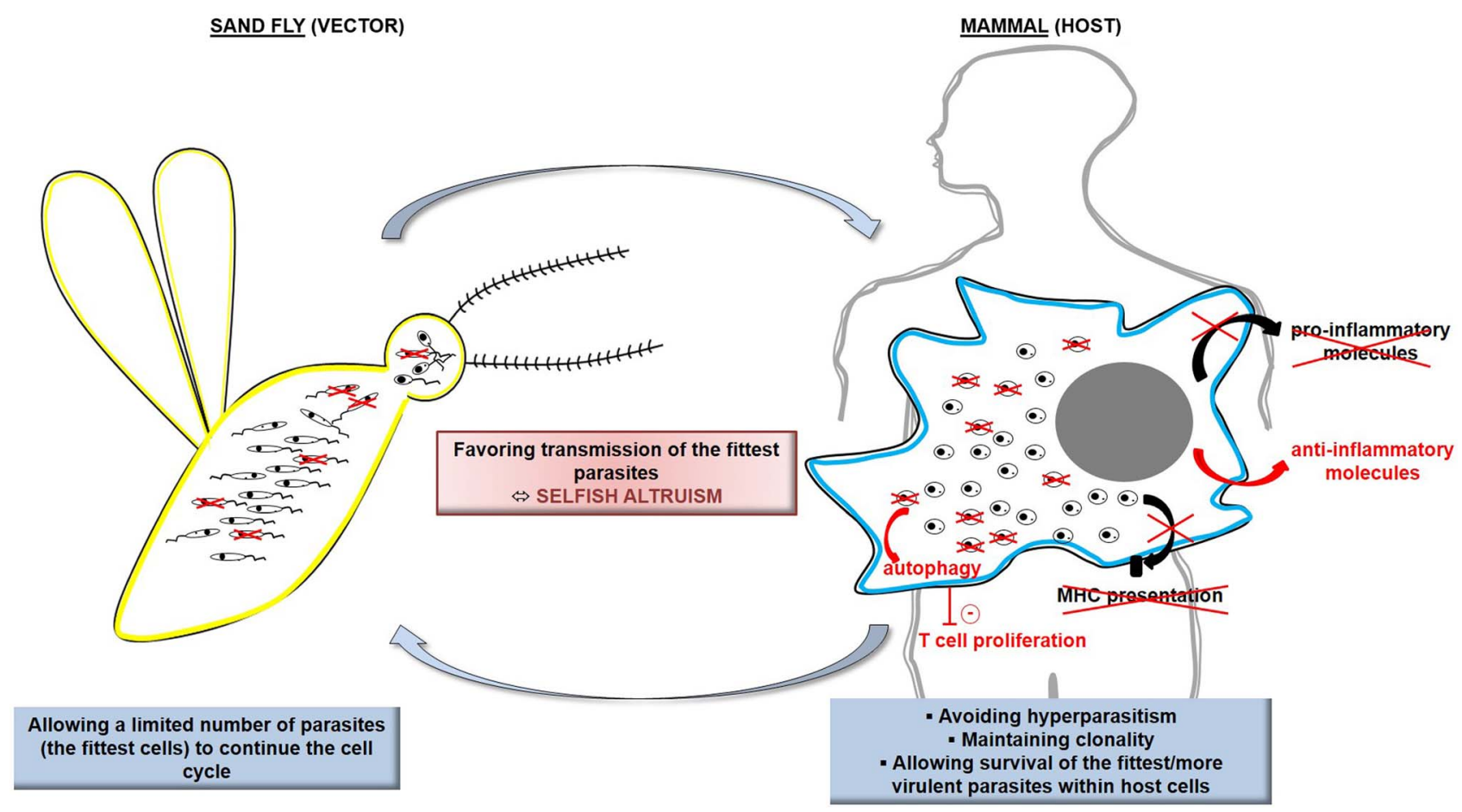

Figure 1. Schematic representation of the physiological roles of Leishmania RCD. In the sand fly vector, Leishmania RCD allows a limited number of parasites, among the fittest, to continue the cell cycle, which is of particular interest because of the limited resources within the vector digestive tract. In the mammalian host, Leishmania RCD induces elimination of damaged/unfit cells, inhibition of the secretion of proinflammatory molecules and, on the contrary, secretion of anti-inflammatory molecules by the infected macrophage, inhibition of parasite antigen presentation, and activation of the macrophage autophagy machinery which negatively regulates $\mathrm{T}$ cell proliferation. Ultimately, this makes it possible to avoid hyperparasitism, to maintain Leishmania clonality, and to ensure survival of the fittest more virulent parasites. As a conclusion, Leishmania RCD appears as a selfish altruism, favoring transmission of the fittest parasites.

can be inhibited or delayed by pharmacologic or genetic inhibition of the autophagic molecular machinery [40].

\section{Physiological roles of Leishmania RCD}

The controlled suicide of cells in multicellular organisms is a clearly accepted process, allowing the disposal of superfluous cells during organism development or damaged cells that would compromise the whole organism [26]. In unicellular organisms such as protozoan parasites, the existence of cell suicide has long been a matter of debate until the demonstration of several roles of $\mathrm{RCD}$, in vivo, in the biology of the organism. In Leishmania, RCD appears to regulate the parasitic population in response to the limited resources in the sand fly gut $[43,72]$. For instance, promastigotes that are not differentiated into the metacyclic infectious form would enter RCD, which would be beneficial for metacyclics since procyclics would not consume essential nutrients found in restricted quantities in the sand fly gut [21]. As a consequence, RCD appears to be an altruistic mechanism for selection of parasites suitable for disease transmission. RCD also appears to regulate parasite density within the host, to avoid hyperparasitism that would kill the host and thus prevent parasite transmission [14, 47]. RCD seems to maintain clonality of the parasitic population, removing non-suitable cells and thus ensuring propagation of the fittest, more virulent cells [63]. Furthermore, it has been demonstrated that phagocytosis of apoptotic Leishmania cells induces secretion, by macrophages, of anti-inflammatory molecules such as IL-10 and TGF- $\beta$ or lipids such as lipoxin A4; on the contrary, it induces inhibition of the secretion of pro-inflammatory cytokines such as TNF- $\alpha$ and lipids such as leukotriene B4 [67, 70]. In case of disposal of apoptotic parasites from a virulent population, Leishmania cells do not survive within phagocytic cells in vitro and lose their ability to induce the disease in vivo $[67,70]$. Phagocytosis of apoptotic cells also appears to decrease presentation of parasite antigens by macrophages [74]. Lastly, apoptotic cells activate the autophagic machinery of the host cells, reducing $\mathrm{T}$ cells proliferation and thus favoring parasite survival [19]. In other words, apoptotic Leishmania parasites allow, in an altruistic manner, the intracellular survival of the fittest parasites. The term "selfish altruism" has been introduced for qualifying RCD in protozoan parasites: an altruistic phenomenon implemented for the whole population that is clonal [24]. Figure 1 illustrates these physiological roles of Leishmania RCD.

\section{Apoptosis phenotype in Leishmania}

In Leishmania, different stimuli induce a phenotype similar to mammalian apoptosis in vitro, such as heat shock, reactive 
oxygen species (nitric oxide, hydrogen peroxide), antiinfectious molecules (such as novobiocin or amphotericin B), anti-cancer molecules (such as miltefosine or doxorubicin), molecules from plants (such as whitaferin A, camptothecin or aloe vera extracts) or lipids (such as edelfosine) (summary in $[38,64])$. These stimuli induce cell rounding, cell shrinkage, plasma membrane changes with maintenance of its integrity, mitochondrial modifications, chromatin condensation, nuclear fragmentation and DNA fragmentation [38]. Extensive inhibition of mRNA translation is also observed during Leishmania cell death, this inhibition being correlated to the fragmentation of antisense RNA complementary to ribosomal RNA [54]. As apoptosis is defined on cell morphology, the term "apoptosis" should be used for this type of Leishmania cell death and other words like "apoptosis-like cell death" or "programmed cell death" should be avoided.

To be more precise, molecular characterization of Leishmania cell death should be carried out. However, the limited knowledge of proteins involved in Leishmania cell death prevents this approach. As a consequence, Leishmania apoptosis is still described on cell morphology and we think that new terms, such as microptosis [23], should be avoided while transduction signals are not known. Furthermore, demonstrating that a stimulus induces Leishmania apoptosis needs to take into account Leishmania particularities. For instance, no membrane blebbing and no apoptotic bodies have been observed in Leishmania cells undergoing apoptosis [38]. Furthermore, the small size of the parasite, and consequently of its nucleus, makes it difficult to show chromatin condensation by fluorescence microscopy. In addition, Annexin $\mathrm{V}$ is not an apoptosis marker in Leishmania [71]. In higher eukaryotes, this molecule binds to phosphatidylserine, a phospholipid naturally present in the inner plasma membrane leaflet that switches to the outer leaflet during apoptosis [50]. In Leishmania parasites, while no phosphatidylserine could be detected, Annexin V can bind to other phospholipid classes [71]. As a consequence, Annexin V staining is a marker of plasma membrane modifications but not an apoptosis marker in Leishmania. On the contrary, a new apoptotic marker has been described in Leishmania: calcein. Interestingly, used in combination with propidium iodide (PI), calcein allows discrimination between healthy, early apoptotic, late apoptotic and necrotic cells [4]. Lastly, since Leishmania parasites lack caspases, the key enzymes of metazoan apoptosis [59], no conclusions can be drawn from experiments highlighting caspase-like activity until the molecular characterization of the enzymes involved.

Moreover, to demonstrate Leishmania apoptosis, specific markers should be used. Clearly, morphologic changes, such as cell rounding or cell shrinkage, cannot be used as a specific apoptotic marker since it can appear under other stress conditions. In the same manner, mitochondrial depolarization, preceded by transient hyperpolarization in Leishmania [38], and the loss of plasma membrane integrity are not specific apoptosis markers.

Apoptosis must also be distinguished from other processes, specifically autophagy. Despite their opposite functions, cell death and the survival process autophagy are closely linked: besides their reciprocal inhibition, each process can activate the other [48]. Autophagy can in particular induce apoptosis by degrading parts of the cell after sequestration in autophagosomes and degradation within lysosomes, or by activating the apoptotic pathway [48]. In Leishmania, autophagic cells enter apoptosis in the absence of nutrients [7]. This close relationship often establishes confusion between the apoptotic and autophagic processes, some authors talking about apoptosis in response to nutrient deprivation or during the stationary phase of Leishmania, while these stimuli induce autophagy [10].

As a consequence, we propose unified criteria for the definition of Leishmania apoptosis as has recently been done in yeast [15] (Fig. 2). We propose to first demonstrate Leishmania cell death by evaluating loss of viability by a growth curve and loss of plasma membrane integrity by PI staining. As a second step, we recommend defining the type of cell death, here apoptosis, by showing the presence of at least two apoptotic markers among DNA fragmentation, cell rounding, cell shrinkage, plasma membrane modifications and mitochondrial depolarization. To evaluate DNA fragmentation, a TUNEL assay should be preferred to an experiment showing the DNA ladder because the latter could be difficult to do [38]. DNA fragmentation, cell rounding, cell shrinkage and plasma membrane modifications evaluated by Annexin V staining make it possible to distinguish apoptosis from autophagy, since these features are not present in autophagic cells [7]. Furthermore, apoptosis kinetics should be carried out to evaluate the entry of healthy cells into early apoptosis and then into late apoptosis. Late apoptotic cells being indistinguishable from necrotic cells, this ensures that the cells die from apoptosis. To supplement this approach, contrary to what is recommended in yeast [15] and metazoans [29], the regulatory network cannot be assessed in Leishmania since the executioner proteins and the metabolic pathways involved are currently unknown.

\section{Proteins involved in Leishmania apoptosis}

In spite of the clear existence of Leishmania apoptosis and several studies on this phenomenon, it remains largely unknown. This is due to the fact that key proteins involved in mammalian apoptosis could not be identified in Leishmania, even bio-informatically. More precisely, caspases, cell death receptors and anti-apoptotic molecules could not be identified [64]. Recently, several proteins that seem to be involved in Leishmania cell death have been identified. Below, we describe the proteins that are currently known.

\section{The endonuclease $\mathbf{G}$ (EndoG)}

EndoG has been well characterized in C. elegans and mammals: it is a cell death effector that localizes in the mitochondria and translocates to the nucleus in response to apoptotic stimuli where it degrades DNA [46, 56, 66]. Concerning Leishmania, EndoG has been identified and well-characterized in two species, showing a similar function as in other organisms: LdBPK_100600.1 in L. donovani and LINF_100012900 in L. infantum [11, 31, 61]. More precisely, in both species, the enzyme possesses nuclease activity in vitro, depending on the three conserved catalytic amino acid residues ( $\mathrm{R}, \mathrm{G}$ and $\mathrm{H}$ ) 


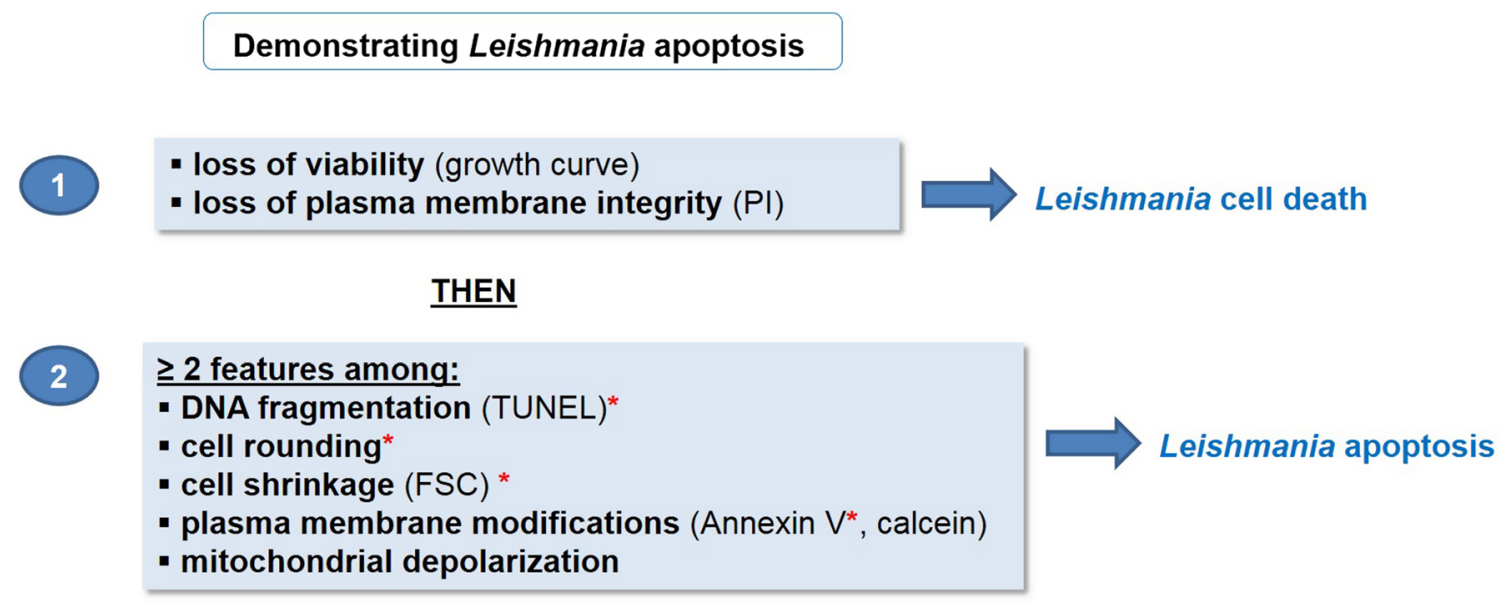

+ kinetics: healthy cells $\longrightarrow$ early apoptotic cells $\longrightarrow$ late apoptotic cells

Figure 2. Proposed procedure to demonstrate Leishmania apoptosis. To demonstrate Leishmania apoptosis, we propose to first show cell death in general by assessing the loss of viability by establishing a growth curve and the loss of plasma membrane integrity by PI staining. Second, the type of cell death should be evaluated. In case of apoptosis, at least two apoptotic markers should be highlighted, among which DNA fragmentation (by a TUNEL assay which is easier than showing a DNA ladder), cell rounding, cell shrinkage (by evaluating Forward Side Scatter (FSC) by flow cytometry), plasma membrane modifications (by Annexin V or calcein staining) and mitochondrial depolarization. Asterisks indicate markers that are not present in autophagic cells. Apoptosis kinetics should also be evaluated, showing entry of healthy cells into early apoptosis and then into late apoptosis, to distinguish apoptosis from necrosis.

$[11,31,61]$. Under normal conditions, the enzyme is localized in the mitochondrion of promastigotes as well as of axenic amastigotes [11,31, 61], where it appears to be essential for parasite survival [62]. In the mitochondrion, where the $\mathrm{pH}$ is relatively high, a small amino acid sequence inhibits the nuclease activity [53]. Different apoptotic stimuli, such as $\mathrm{H}_{2} \mathrm{O}_{2}$ or edelfosine, induce EndoG translocation from the mitochondrion to the nucleus where it forms a complex, on the one hand, with the Flap endonuclease-1 FEN-1 and, on the other, with the nuclease TatD [11]. This results in DNA degradation through endonuclease and exonuclease activities, notably on singlestranded DNA [11, 31, 61, 62]. As a consequence, despite unique properties of Leishmania EndoG compared to other EndoG [53], this enzyme is a well-characterized cell death effector in the parasite.

\section{Metacaspase}

Metacaspases are cysteine peptidases that have been identified in fungi, plants and protozoa. They possess a caspase-like domain homologous to the p20 subunit of caspases, with the catalytic dyad histidine/cysteine, and a C-terminal proline-rich domain homologous to the p10 subunit of caspases [35, 65, $68,73]$. However, while caspases are specific to substrates containing an aspartate at $\mathrm{P} 1$ position, metacaspases are specific to substrates with an arginine or lysine [35, 52,68]. Metacaspases have been studied in different Leishmania species where they share a high percentage of identity, the catalytic dyad histidine 147 and cysteine 202 and cleavage sites (notably arginine at position 63, 136, 218 and 298) (Fig. 3).

In $L$. major, the metacaspase, termed LmjMCA, encoded by the LmjF.35.1580 gene, is expressed in the different parasite forms: in the logarithmic and stationary promastigotes, as well as in the amastigotes [2, 35]. It is localized mainly in the cytoplasm, but also in the single mitochondrion thanks to an N-terminal localization signal [2, 73]. More precisely, localization of LmjMCA is modified during the cell cycle, being distributed in the whole cytoplasm during interphase, and being associated with the kinetoplast, the mitochondrial DNA, during organelle segregation or with the nuclear mitotic spindle during mitosis [2]. One hypothesis is that mitochondrial translocation is prevented by a short sequence of LmjMCA, explaining its cytoplasmic localization [73]. LmjMCA has no caspase-like activity but it possesses trypsine-like activity towards arginine at position P1 that depends on the catalytic dyad H147/C202 $[35,49]$. However, it is involved in apoptosis as caspases. Indeed, the expression of LmjMCA in S. cerevisiae yeasts lacking the endogenous metacaspase YCA1 restores the apoptotic phenotype after oxidative stress, this restoration being dependent on the presence of the LmjMCA catalytic dyad [35]. Furthermore, overexpression of LmjMCA induces $L$. major apoptosis after heat shock, oxidative stress or the addition of an anti-leishmanial drug (miltefosine or curcumin) [73], while its deletion inhibits miltefosine- and curcumin-induced apoptosis [16]. More precisely, apoptotic stimuli induce auto-processing of LmjMCA depending on the catalytic dyad, releasing the catalytic domain, at least from amino-acids 136 to 218 , containing the catalytic dyad His147/Cys202, after cleavage of the C-terminal domain $[35,73]$. It seems that the catalytic domain released induces apoptosis via the catalytic cleavage of substrates, while the proline-rich C-terminal domain that has been released during apoptosis interacts with proteins involved in stress regulation and apoptosis such as the mitogen-activated protein kinase LmaMPK7 and the calpain-like protease LmCALP27.2 [16]. It has also been shown that LmjMCA is involved in the cell survival process autophagy in $L$. major 
$\mathrm{N}$-ter

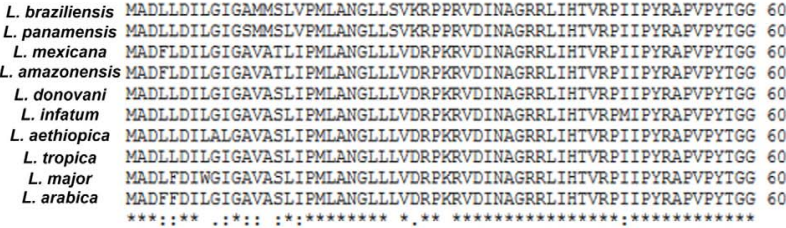

panamensis RTRALFIGINYTGTGNELOGCVNDVRLMLGILQQISFPISECCILVDDSFPGFTGMPTR

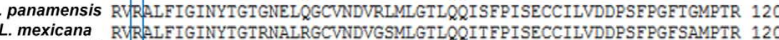
amazonensis RYRALFIGINYTGTRNALRGCVNDVGSMLGILQQITFPISECCILVDDPSFPGFSAMPTR 120 L. donovani RYRALFIGINYTGMRNALRGCVNDVSSMLGILQQISFPISECCILVDDPSFPGFCGMPTR 120 L. infatum RYRALFIGINYTGMRNALRGCVNDVSSMLGILQQISFPISECCILVDDPSFPGFCGMPTR 120 L. aethiopica RYRALFIGINYTGMRNALRGCVNDVSSMLGTLQQISFPISECCILVDDPSFPGFCGMPTR 120 L. tropica RURALFIGINYTGMRNALRGCVNDVSSMLGILQQISFPISECCILVDDPSFPGFCGMPTR 120 $\begin{array}{ll}\text { L. major } & \text { RYRALFIGINYTGMNALLECVNDVSSMLGILQISFPISECCILVDDPSPGFCGMPTR } 120 \\ \text { L. arabica } & \text { RTRALFIGINYTMRNALRGCVNDVSSMLGIDQISFPISECCILVDDPSPGFCGMPTR } 120\end{array}$

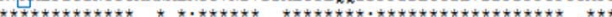

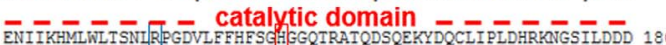
L. braziliensis ENIIKHMLWLISMIRPGDVLFFHFSGHGGQTRATQDSOFEMDQ L. panamensis ENIIKHMLWLTGNIR R PDVLFFHFSGHGGQTRATHDSQEKYDQCLI PLDHRRNGSILDDD 180

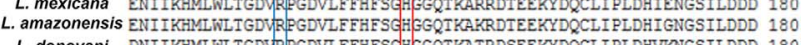
L. donovani DNIIKHMLWLIGDVIRPGDVLFFHFSGHGGQTKATRDSEEKYDQCLIPLDHVRIGSILDDD 180
L infatum

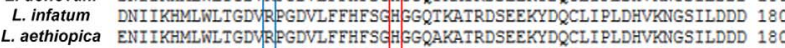
L. tropica ENIIKHULWLIGDYRPGDVLFFHFSGHEGQAKATRDSEEKYDQCLI IPLDHVRKGSILDDD 180 L. major DNIIKHMLWLIGDYRPGDVLFFHFSGHGGQAKATRDSEEKYDQCLIPLDHVKIGSILDDD 180
L. arabica DNIIKHULWLIGDYRPGDVLFFHFSEHGGQAKATRDSDEKYDQCLIPLDHVRIGSILDDD 180 L. braziliensis LFLMLVAPLPPGVMTCVFDCCESASMLDLPFSYVA.TRMGNGGVREHMQQVRRGNYSNGD 240

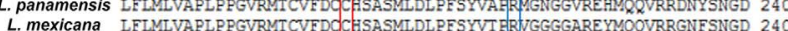
L. amazonensis LFLMLVAPLPPGVRMTCVFDCCHSASMLDLPFSYVI RRVGGGGAREYMQQVVRRGIFSNGD 240

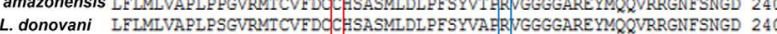

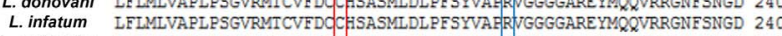
L. aethiopica LFLMLVAPLPSGVRMTCVFDOCHSASMLDLPFSYVAFRVGGGGAREYMQQVRRGNFSNGD 240 L. tropica LFIMLVAPLPPGVRMTCVFDOCISASMLDLPFSYVA.RRVGGGGAREYMQQVRRGNFSNGD 240 L. major LFLMLVAPLPSGVRMTCVFDCC ESASMLDLPFSYVA.RRVGGGGACEYMQQVRRGNFSNGD 240

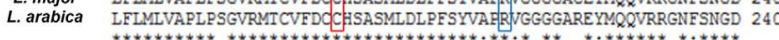
L. braziliensis VMMFSGCTDSGTSADVHNGGHANGAATLAFTWSLLNTHGFSYLNILLKTREETPYKG L. panamensis VWMFSGCTDSGTSADVHNGGHANGAATLAFTWSLLNTHGFSYLNILIKTREELRKKGRV 300 L. mexicana VMMFSGCTDSGTSADVQNGGHANGAATLAFTWSLLNTHGFSYLNILLKTREELRKKGRVQ 300 L. donovani VWMFSGCTDSGTSADVQNGGHANGAATLAFTWSLLNTHGFSYLILLKTREELRKKGRVO 300 L. infatum VVMFSGCTDSGISADVQNGGHANGAATLAFTWSLINTHGESYLNILLKTREELRKKGRVQ 300 L. aethiopica VWMFSGCTDSGTSADVQNGGHANGAATLAFTWSLLNTHGFSYLIILLKTREELRKKGPVV 300 L. tropica VWIFSCTDSGTSADVQNGGHANGAATLAFTWSLLNTHGFSYLNILLKTREELRKKGRVQ 300
L. major VWFSGCTDRGTSADVQNGGHANGAATLAFTWSLLNTHGLSYLNILLKTRELRKKGRVQ 300 $\begin{array}{ll}\text { L. major } & \text { VNAFSGCTDRGTSADVQNGGHANGAATLAFTWSLLNTHGLSYLNILLKTREELRKKGRVQ } 300 \\ \text { L. arabica } & \text { VWFSGCTDRGISADVQNGGHANGAATLAFTWCLLNTHGFSYLNILLKTRELLRKKGEVQ } 300\end{array}$

L. braziliensis VPQLTSSKPIDLYKPFSLFGMVTVNASMMHFVPQQFQQRPQNLPPQAMPPPAGYPAYAPP 360

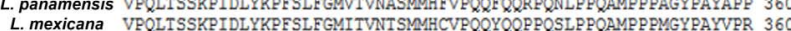
L. mexazonensis VPQITSSKPIDLYKPFSLFGMITVNTSMMHCVPQQYHQPPQSLPPQMMPPPNGYPAYVPR 360 L. donovani VPQLTSSKPIDLYKPFSLFGMITVNASMMHCVPQYQQRPPQSLPPQAMPPPAGYVVHVPP 360 L. infatum VPQLTSSKPIDLYKPFSLFGMITVNASMMHCVPQQYQQR PQSLPPQAMPPPAGYPVHVPP 360 L. aethiopica VPQLISSKPIDLYKPFSL FGMITVNASMMHCVPLQY QQRPQSLPPQAMPP-------- 350 $\begin{array}{ll}\text { L. tropica } & \text { VPQLISSKPIDLYKPFSLFGMITVNASMMHCVPQQYQQRPQSLPPQAMPP--------- } 350 \\ \text { L.major } & \text { VPQLISSKPIDLYKPFSLFGMITVNASMMHCVPQQYQQRPQSLPPQVMPPATGYPVHVPP } 360\end{array}$ $\begin{array}{ll}\text { L. major } & \text { VPQLISSKRPIDLYKPFSLFGMITVNASMMHCVPQQYQQRPPQSLPPQVMPPATGYPVHVPP } 360 \\ \text { L. arabica } & \text { VPQLITSSKPIDLYKPFSLFGMITVIASMMHCVPQQYQRLPPSLPPQAMPPATGYPVHVPP } 360\end{array}$ C-ter

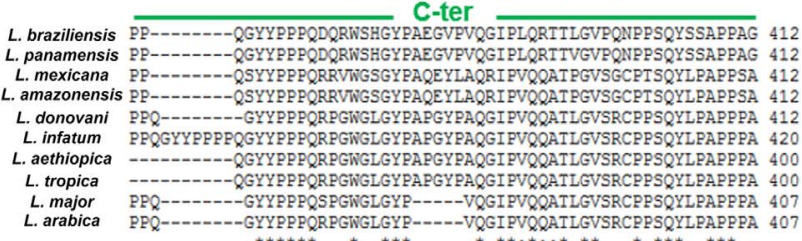

L. braziliensis QYAPRQ-----PQQVPPAQYTFSSVPPR 435

L. panamensis QYAPRQ-----PPQAPPAQYTFSSVPPR 435

L. amazonensis PYAPPPARQYGPOOPPAQYTEGRIPG 440

L. donovani LYAPPPPGQHGPPQPPPAQYT FSPLPPR 440

L. infatum LYAPPPPGQHGPPQPPPAQYT ESPLPPR 443

L. aethiopica VYAPPPLGQHGPPQPPPAQYTFSPLPPR 423

L. tropica VYAPPPPGQHGPPQPPPAQYTFSPLPPR 42

$\begin{array}{ll}\text { L. major } & \text { VYAPPPPGRGPPQPPPAQYTFSPLPPG } 435 \\ \text { L. arabica } & \text { AYAPPPPGQRGPPOPPPAOYTESPFPPG } 435\end{array}$

Figure 3. Alignment of the amino-acid sequences of the MCA orthologs in different Leishmania species. The N-terminal domain, which contains a mitochondrial localization signal, from amino-acids 1 to 62 , is indicated in blue; the catalytic domain, containing the catalytic dyad histidine 147/cysteine 202 (boxed in red), is indicated by a dashed red line; the proline-rich C-terminal domain is indicated by a green line. Demonstrated cleavage sites are boxed in blue: R63, R136, R218 and R298.
[16], underlying a broader role of LmjMCA than only in cell death as already demonstrated for caspases [22, 37, 42].

In $L$. donovani, two metacaspases have been described: LdMC1 (DQ367530) and LdMC2 (DQ367531) [44]. However, LdMC2 does not appear in the TriTryp database (https://tritrypdb.org/tritrypdb/), it has the same sequence as LmjF.35.1580 and experiments have been done with LdMC1 or LdMC antibodies that do not discriminate between both proteins, raising the question of the nature of LdMC2. Concerning $\mathrm{LdMC1}$, it is expressed in promastigotes and axenic amastigotes [44]. Contrary to LmjMCA, it seems that it is not processed in wild-type and apoptotic conditions [44]. It is localized in acidocalcisomes, where acidic $\mathrm{pH}$ may inhibit its activity [44]. It has no caspase-like activity, explaining the absence of effects of caspase inhibitors, but possesses trypsine-like activity, cleaving substrates containing an arginine or a lysine at position P1 [44]. Lastly, LdMC1 seems to be involved in $L$. donovani $\mathrm{H}_{2} \mathrm{O}_{2}$-induced apoptosis after release from the acidocalcisomes [44]. Some authors indicate that LdMC1 is involved in L. donovani survival [60]. However, the use of markers that are not specific to apoptosis and/or experiments that are difficult to interpret underlines the need for further experiments to draw such conclusions.

The third and last Leishmania species in which the role of metacaspase in cell death has been studied is L. mexicana, which contains a single metacaspase here termed MCA encoded by the LmxM.34.1580 gene. This metacaspase, mainly localized in the cytoplasm, seems involved in L. mexicana miltefosine-induced apoptosis at least in promastigotes, cells lacking the corresponding gene being less susceptible to the pro-apoptotic drug miltefosine [17]. However, MCA-deficient L. mexicana cells have no different susceptibility towards oxidative stress or towards the camptothecin drug [17]. In L. mexicana, MCA is also a negative regulator of intracellular amastigote proliferation [17].

These data on metacaspases in different Leishmania species, summarized in Table 1 , are not necessarily mutually exclusive and do not preclude similar roles in the different species. Metacaspase could be involved in the Leishmania cell cycle and regulation of the intracellular amastigote proliferation irrespective of the species, and could be recruited in the presence of an apoptotic stimulus to take part in cell death.

\section{Aquaporin Li-BH3AQP}

Li-BH3AQP is an aquaporin identified in L. infantum, encoded by the LINF_220020300 gene, and that contains a $\mathrm{Bcl}-2$ homology domain called $\mathrm{BH} 3$, found in Bcl-2 family proteins i.e. pro- and anti-apoptotic molecules [32]. This protein can bind to the anti-apoptotic molecule $\mathrm{Bcl}-\mathrm{X}_{\mathrm{L}}$ in mammalian cells and its expression in mammalian cells reduces cell viability [32]. In L. infantum, Li-BH3AQP, which is mainly perinuclear, has a pro-death activity dependent on key residues of the BH3 domain, reducing cell viability and inducing DNA fragmentation after the addition of pro-apoptotic stimuli such as staurosporine and antimycin A [32]. This protein also has pro-survival activity in nutrient deprivation or hypotonic stress conditions, this activity being independent of key residues of 
the $\mathrm{BH} 3$ domain [32]. Li-BH3AQP constitutes the first, and for the moment the only, non-enzymatic molecule identified as being involved in Leishmania cell death. However, the absence, at this time, of anti-apoptotic molecules identified, such as Bcl$\mathrm{X}_{\mathrm{L}}$, raises the question of the role of $\mathrm{Li}-\mathrm{BH} 3 \mathrm{AQP}$ in the parasite itself or in the host cell after release from the parasite [33]. Furthermore, additional experiments are required to evaluate the importance of this protein in cell death in other Leishmania species.

\section{Calpains}

Calpains (calcium-activated papain-like proteases) are cysteine proteases that are calcium-dependent [34]. In mammals, typical calpains are involved in a broad range of cellular functions such as differentiation, proliferation, apoptosis, cell survival, cytoskeletal rearrangements and cell migration [58]. In Leishmania, like in other Trypanosomatids, several calpain-like proteins, much more than in mammals, have been described [27]. They include proteins with a well-conserved protease domain that are called CALP (calpain-like proteins) and short calpain-like proteins with a highly conserved $\mathrm{N}$-terminal domain but that lack a protease domain, called SKCRP (small kinetoplastid calpain-related proteins) [27]. All Leishmania calpain-like sequences lack the C-terminal calmodulin-related calcium-binding domain found in most mammalian calpains [27]. Furthermore, the protease domain, when present, often lacks the catalytic triad cysteine/histidine/asparagine, which is critical for mammalian calpain catalytic activity, raising the question of their protease activity [27]. The presence of a high number of calpain-related proteins and their unique protein architecture suggest important Leishmania-specific functions. However, these functions are still a matter of debate, particularly concerning their involvement in parasite apoptosis. The involvement of calpain-like proteins in Leishmania cell death has been reported [3, 36]. However, calpain inhibitors do not have an effect on amphotericin B-induced apoptosis: they do not inhibit caspase-specific substrate PPL cleavage activity, do not decrease PI staining, and do not inhibit loss of mitochondrial membrane potential [43]. On the contrary, calpain inhibitor I inhibits apoptosis after NO treatment [36]. Additionally, in a contradictory manner, the same calpain inhibitor partly inhibits miltefosine-induced DNA fragmentation but does not prevent cell shrinkage [55]. Concerning calpainrelated proteins, few experiments have been carried out to study their role in Leishmania apoptosis. One SKCRP, SKCRP14.1, which is downregulated in an antimonial-resistant strain, increases antimonial-induced apoptosis but protects from miltefosine-induced apoptosis [69]. Moreover, a yeast two-hybrid assay has shown that the calpain-like cysteine peptidase LmCALP27.2 encoded by the LmjF.27.0500 gene interacts with the C-terminal domain of LmjMCA, which was confirmed by co-immunoprecipitation [16]. This protein, as well as six other L. major calpain-related proteins, was also overrepresented in $L$. major cells treated with the pro-apoptotic drug miltefosine in comparison to untreated cells. More precisely, LmCALP4.1, LmCALP18.1, LmCALP20.1, LmCALP27.1, LmCALP27.2, LmCALP31.1 and LmSKCRP25.2 are from 3 to 49 times more expressed in the miltefosine-treated sample than in the untreated sample (Basmaciyan et al., submitted article). The fact that, among the calpain-related proteins identified as potentially involved in Leishmania apoptosis, only LmCALP4.1 contains a conserved catalytic triad suggests that these three aminoacid residues are not necessary for protein apoptotic activity. As a conclusion, at least some calpain-related proteins are involved in Leishmania apoptosis and the heterogeneity in the results could be due to the different apoptotic stimuli that have been used.

\section{Cathepsin B-like protein (CPC)}

Cysteine proteinase $\mathrm{C}(\mathrm{CPC})$, a cathepsin B-like protein, has been shown to be a cell death effector in Leishmania [25]. This enzyme, encoded by the gene LmjF.29.0820 in L. major, binds to the pan-caspase inhibitor Z-VAD-FMK [25]. Upon addition of an apoptotic stimulus such as miltefosine or heat shock, CPC is released from lysosomes to the cytosol, where it induces Leishmania apoptosis [25]. The rupture of the lysosomal membrane during Leishmania apoptosis could also explain the release of other cell death effectors, particularly other cathepsins like CPA and CPB [25, 74].

\section{LmjHYD36 and Lmj.22.0600}

Recently, two new proteins have been identified as cell death effectors in L. major: LmjHYD36 and LmjF.22.0600 $[6,8]$. Orthologs of both proteins are overexpressed during L. infantum differentiation from the promastigote (in the insect vector) to the amastigote (in the mammalian host) form $[1,51]$, during which autophagy occurs [10]. LmjHYD36 is encoded by the LmjF.36.6540 gene. It contains the catalytic triad (cysteine, histidine and aspartic acid) characteristic of $\alpha / \beta$-hydrolases and is highly conserved among Leishmania species [8]. In the TriTryp database, this protein is annotated as a potential endonuclease. However, the lack of a positive patch for DNA binding at the protein surface and the lack of clear nuclease activity in vitro challenge this function [8]. Overexpression of the LmjHYD36 gene increases pentamidineinduced cell death, while its deletion inhibits cell death induced by pentamidine [8]. As a consequence, LmjHYD36 is an effector of the pentamidine-induced cell death pathway. LmjHYD36 is also involved in Leishmania cell death induced by curcumin and miltefosine but not by $\mathrm{H}_{2} \mathrm{O}_{2}$ [8].

LmjF.22.0600 is a potential acetyltransferase conserved among different Leishmania species. The corresponding gene is overexpressed in L. major cells after the addition of different pro-apoptotic drugs, and gene overexpression increases the apoptosis induced by curcumin and miltefosine [6]. On the contrary, deletion of LmjF.22.0600 by CRISPR/Cas9 induces no significant difference concerning Leishmania cell death, suggesting that another protein can take over in the apoptotic pathway. This suggests the importance of LmjF.22.0600 for Leishmania cells [6]. Furthermore, LmjF.22.0600 is involved in the same apoptotic pathway as LmjMCA. In fact, Lmjmca expression is required for $L m j F .22 .0600$ expression and overexpression of $L m j F .22 .0600$ has no consequence on pentamidine-induced cell death, while pentamidine induces L. major apoptosis independently of LmjMCA [5, 6]. 


\section{Apoptosis pathways}

Like in mammals, where different apoptotic pathways have been described, for example caspase-dependent and caspaseindependent pathways [13], several apoptotic pathways are being described in Leishmania. More precisely, concerning MCA, three apoptotic pathways have been identified in L. major: (i) a "classic" apoptotic pathway involving LmjMCA activation (induced by miltefosine), (ii) an original pathway involving LmjMCA inhibition (induced by amphotericin B, curcumin and $\mathrm{H}_{2} \mathrm{O}_{2}$ ) in which either LmjMCA inhibition directly induces apoptosis through its role in autophagy [16], autophagy inhibition inducing apoptosis [48], or its inhibition is not related to the apoptosis process, and (iii) an LmjMCAindependent pathway (induced by pentamidine). In the last case, several other proteases could be involved, such as calpains or cathepsins. Figure 4 illustrates these results.

Concerning LmjHYD36, as explained above, it is an effector of the pentamidine-induced cell death pathway but, on the contrary, it is not involved in the $\mathrm{H}_{2} \mathrm{O}_{2}$-induced apoptotic pathway [8]. Furthermore, LmjHYD36 is involved in cell death induced by curcumin in an LmjMCA-independent manner, curcumin inducing overexpression of the LmjHYD36 gene in the wild-type strain as well as in the LmjMCA-deficient strain [8]. Lastly, while the LmjHYD36 gene is overexpressed in the wild-type strain after the addition of miltefosine, no overexpression occurs in the LmjMCA-deficient strain, suggesting that LmjHYD36 acts downstream of LmjMCA in the miltefosineinduced apoptosis pathway [8]. As a consequence, $\mathrm{H}_{2} \mathrm{O}_{2}$ and amphotericin B could induce L. major apoptosis through proteins other than LmjMCA or LmjHYD36, not known at this time (Fig. 4). Miltefosine could induce the activation of LmjMCA that could activate LmjHYD36, both proteins being at the origin of the apoptotic phenotype (Fig. 4). On the contrary, curcumin would only activate LmjHYD36 (Fig. 4). Whether curcumin inhibits LmjMCA or has no direct action on LmjMCA remains to be determined. Finally, pentamidine may induce LmjHYD36 but not LmjMCA activation (Fig. 4).

As shown previously, LmjMCA is necessary for LmjF.22.0600 expression and LmjF.22.0600 is not involved in the pentamidine-induced metacaspase-independent pathway [6]. The protein LmjF.22.0600 is thus downstream of LmjMCA in the proposed model (Fig. 4).

EndoG is activated by $\mathrm{H}_{2} \mathrm{O}_{2}$ [31] and the article from Chowdhury et al. [18] suggests that EndoG acts downstream of LmjMCA, allowing us to complete Figure 4. Finally, authors suggest that antimonials induce a cell death pathway different from the one induced by miltefosine in Leishmania [69]. However, other experiments must be conducted to identify the cell death pathways induced by antimonials and thus to complete our proposed model.

\section{Targeting Leishmania cell death}

Because of the importance of cell death in the parasite biology, the specificity of the proteins and the cell death pathways involved, and the absence of several proteins in humans, proteins involved in Leishmania cell death appear to be a target of choice for the development of new therapeutic tools. To this 


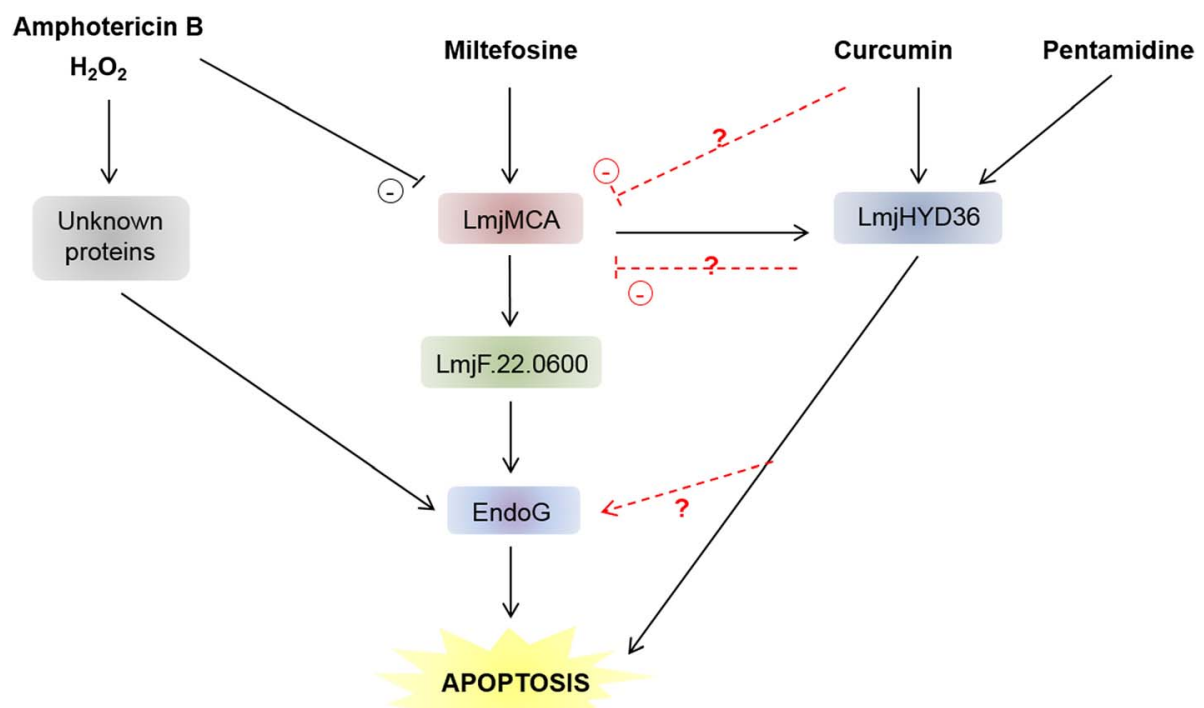

Figure 4. Proposed model of the different $L$. major cell death pathways. It is currently clear that different pro-apoptotic stimuli can induce different cell death pathways in L. major. While miltefosine induces LmjMCA and then LmjHYD36 and LmjF.22.0600 activation before activating EndoG, the amphotericin $\mathrm{B}$ and $\mathrm{H}_{2} \mathrm{O}_{2}$-induced cell death pathways involve unknown proteins. Curcumin and pentamidine, on the contrary, only activate LmjHYD36. The relationships between curcumin and LmjMCA and between LmjHYD36 and LmjMCA, on the one hand, and EndoG on the other, remain to be elucidated.

end, proteins and signaling pathways involved must be identified in a more exhaustive manner. For this purpose, two methods can be proposed. The first one consists in identifying the proteins overexpressed during Leishmania cell death. This type of approach has been attempted by our group, highlighting the importance of calpains in Leishmania cell death (Basmaciyan et al., submitted article). However, these results must be supplemented and/or confirmed. For those who cannot do proteomics, proteins involved in Leishmania autophagy or at least in Leishmania differentiation from the promastigote to the amastigote form, during which autophagy occurs, appear a great source because of the close relationship between autophagy and apoptosis [48]. This approach allowed the recent identification of LmjHYD36 [8] and LmjF.22.0600 [6]. The second method consists in identifying protein partners or substrates. For instance, MCA being involved in Leishmania apoptosis, at least in some signaling pathways, the identification of MCA substrates will allow the identification of apoptosis effectors in Leishmania. Importantly, the cleavage sites of LmjMCA have been identified in vitro, different small peptides being good LmjMCA substrates: GGR, GRR, RR and VRPR [35, 49]. We thus listed the potential cleavage sites in all L. major proteins, as a source of potential LmjMCA substrates (Table S1).

Once proteins involved in Leishmania cell death have been identified, they can be targeted. Once again, several options are possible. First, owing to the necessity of Leishmania cell death in the biology of the parasite, the inhibition of this process thanks to specific inhibitors could constitute a new therapeutic approach. For instance, LmjMCA-binding peptides may be of interest for inhibiting L. amazonensis heat shock-induced death [57]. However, even though MCA seems to have a role similar to that of caspases in cell death, caspase inhibitors have no action on it [16, 44]. Specific MCA inhibitors must thus be used, which suggests weak cytotoxicity of the molecules towards host cells. Cross-talk between different cell death pathways, emphasized in other eukaryotes [29] and suggested in Leishmania, is nevertheless an issue for this approach, as inhibiting cell death implies inhibiting several pathways at the same time. As a consequence, activation of the apoptotic pathways seems more likely. Since the pathways are specific to the parasite, such activators would not affect mammalian host cells. Furthermore, Leishmania cell death by apoptosis would not induce a host immunological response, contrary to necrosis. To induce Leishmania cell death, proteins/peptides involved in parasite death can be fused to a cell permeant peptide after checking that it does not induce conformation changes. Catalytic proteins/peptides can also be encapsulated, for instance in lipidic vectors, allowing their passage through the different membranes to target the intracellular amastigotes and induce their death. This approach could even be applied for other intracellular infectious agents, such as Plasmodium falciparum.

\section{Conclusion}

The recent discovery of several proteins as cell death effectors indicates that Leishmania cell death is regulated and not incidental, as previously suggested [59]. However, the knowledge on Leishmania cell death is less advanced than on other eukaryotes, whether higher eukaryotes or ancestral eukaryotes, such as yeast. The morphological description of Leishmania cell death should notably be withdrawn to the benefit of functional descriptions, since morphology gathers very different features, from totally necrotic to totally apoptotic. This approach will be made possible by a better comprehension of the proteins and pathways involved. It is therefore important not to generalize but to study the consequences of one stimulus at a time in a given species, different stimuli inducing different cell death 


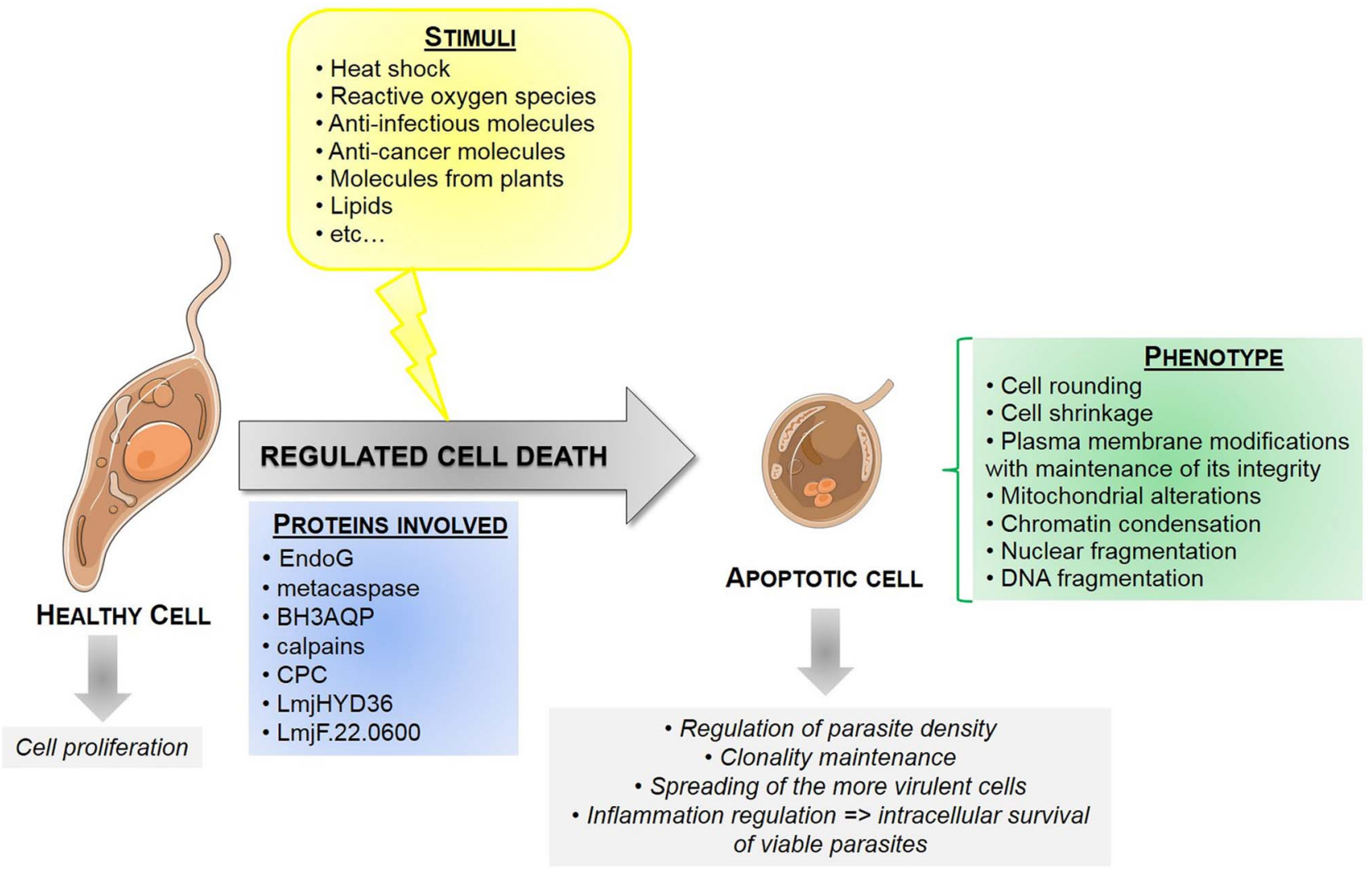

Figure 5. Schematic representation of L. major RCD. This schematization summarizes the physiological roles of Leishmania RCD, the phenotype of apoptosis, the pro-apoptotic stimuli and the proteins involved that are currently known.

pathways. Figure 5 summarizes the data obtained on Leishmania apoptosis, from the potential inducers to the in vivo consequences, through the phenotypic features and the proteins involved. Other experiments must be carried out to confirm that this general scheme applies to all Leishmania species and, especially, in vivo, in physiological conditions.

In conclusion, proteins involved in Leishmania cell death are targets of choice for the development of new therapeutic tools, owing to their high parasite specificity and importance, while leishmaniases still constitute a global health issue with no satisfactory treatment.

\section{Conflict of interest}

The authors declare that they have no conflict of interest.

\section{Supplementary materials}

Table S1. Number of potential LmjMCA cleavage sites.

Supplementary material is available at https://www. parasite-journal.org/10.1051/parasite/2019071/olm

\section{References}

1. Alcolea PJ, Alonso A, Gomez MJ, Sanchez-Gorostiaga A, Moreno-Paz M, Gonzalez-Pastor E, Torano A, Parro V, Larraga V. 2010. Temperature increase prevails over acidification in gene expression modulation of amastigote differentiation in Leishmania infantum. BMC Genomics, 11(1), 31.

2. Ambit A, Fasel N, Coombs GH, Mottram JC. 2008. An essential role for the Leishmania major metacaspase in cell cycle progression. Cell Death \& Differentiation, 15(1), 113-122.

3. Arnoult D, Akarid K, Grodet A, Petit PX, Estaquier J, Ameisen JC. 2002. On the evolution of programmed cell death: apoptosis of the unicellular eukaryote Leishmania major involves cysteine proteinase activation and mitochondrion permeabilization. Cell Death \& Differentiation, 9(1), 65-81.

4. Basmaciyan L, Azas N, Casanova M. 2017. Calcein+/PI- as an early apoptotic feature in Leishmania. PLoS One, 12(11), e0187756.

5. Basmaciyan L, Azas N, Casanova M. 2018. Different apoptosis pathways in Leishmania parasites. Cell Death Discovery, 5, 27.

6. Basmaciyan L, Azas N, Casanova M. 2019. A potential acetyltransferase involved in Leishmania major metacaspasedependent cell death. Parasites \& Vectors, 12(1), 266.

7. Basmaciyan L, Berry L, Gros J, Azas N, Casanova M. 2018. Temporal analysis of the autophagic and apoptotic phenotypes in Leishmania parasites. Microbial Cell, 5(9), 404-417.

8. Basmaciyan L, Jacquet P, Azas N, Casanova M. 2019. A novel hydrolase with a pro-death activity from the protozoan parasite Leishmania major. Cell Death Discovery, 5(1), 99.

9. Bates PA. 2008. Leishmania sand fly interaction: progress and challenges. Current Opinion in Microbiology, 11(4), 340-344.

10. Besteiro S, Williams RAM, Morrison LS, Coombs GH, Mottram JC. 2006. Endosome sorting and autophagy are essential for differentiation and virulence of Leishmania major. Journal of Biological Chemistry, 281(16), 11384-11396. 
11. BoseDasgupta S, Das BB, Sengupta S, Ganguly A, Roy A, Dey S, Tripathi G, Dinda B, Majumder HK. 2008. The caspaseindependent algorithm of programmed cell death in Leishmania induced by baicalein: the role of LdEndoG, LdFEN-1 and LdTatD as a DNA "degradesome". Cell Death \& Differentiation, 15(10), 1629-1640.

12. Bredesen DE. 2000. Apoptosis: overview and signal transduction pathways. Journal of Neurotrauma, 17(10), 801-810.

13. Bröker LE, Kruyt FAE, Giaccone G. 2005. Cell death independent of caspases: a review. Clinical Cancer Research, 11(9), 3155-3162.

14. Bruchhaus I, Roeder T, Rennenberg A, Heussler VT. 2007. Protozoan parasites: programmed cell death as a mechanism of parasitism. Trends in Parasitology, 23(8), 376-383.

15. Carmona-Gutierrez D, Bauer MA, Zimmermann A, Aguilera A, Austriaco N, Ayscough K, Balzan R, Bar-Nun S, Barrientos A, Belenky P, Blondel M, Braun RJ, Breitenbach M, Burhans WC, Buettner S, Cavalieri D, Chang M, Cooper KF, Côrte-Real M, Costa V, Cullin C, Dawes I, Dengjel J, Dickman MB, Eisenberg T, Fahrenkrog B, Fasel N, Froehlich K-U, Gargouri A, Giannattasio S, Goffrini P, Gourlay CW, Grant CM, Greenwood MT, Guaragnella N, Heger T, Heinisch J, Herker E, Herrmann JM, Hofer S, Jiménez-Ruiz A, Jungwirth H, Kainz K, Kontoyiannis DP, Ludovico P, Manon S, Martegani E, Mazzoni C, Megeney LA, Meisinger C, Nielsen J, Nystroem T, Osiewacz HD, Outeiro TF, Park H-O, Pendl T, Petranovic D, Picot S, Polčic P, Powers T, Ramsdale M, Rinnerthaler M, Rockenfeller P, Ruckenstuhl C, Schaffrath R, Segovia M, Severin FF, Sharon A, Sigrist SJ, Sommer-Ruck C, Sousa MJ, Thevelein JM, Thevissen K, Titorenko V, Toledano MB, Tuite M, Voegtle F-N, Westermann B, Winderickx J, Wissing S, Woelfl S, Zhang ZJ, Zhao RY, Zhou B, Galluzzi L, Kroemer G, Madeo F. 2018. Guidelines and recommendations on yeast cell death nomenclature. Microbial Cell, 5(1), 4-31.

16. Casanova M, Gonzalez IJ, Sprissler C, Zalila H, Dacher M, Basmaciyan L, Späth GF, Azas N, Fasel N. 2015. Implication of different domains of the Leishmania major metacaspase in cell death and autophagy. Cell Death \& Disease, 6, e1933.

17. Castanys-Muñoz E, Brown E, Coombs GH, Mottram JC. 2012. Leishmania mexicana metacaspase is a negative regulator of amastigote proliferation in mammalian cells. Cell Death \& Disease, 3, e385.

18. Chowdhury S, Mukherjee T, Chowdhury SR, Sengupta S, Mukhopadhyay S, Jaisankar P, Majumder HK. 2014. Disuccinyl betulin triggers metacaspase-dependent endonuclease G-mediated cell death in unicellular protozoan parasite Leishmania donovani. Antimicrobial Agents \& Chemotherapy, 58(4), 2186-2201.

19. Crauwels P, Bohn R, Thomas M, Gottwalt S, Jäckel F, Krämer S, Bank E, Tenzer S, Walther P, Bastian M, van Zandbergen G. 2015. Apoptotic-like Leishmania exploit the host's autophagy machinery to reduce T-cell-mediated parasite elimination. Autophagy, 11(2), 285-297.

20. da Silva R, Sacks DL. 1987. Metacyclogenesis is a major determinant of Leishmania promastigote virulence and attenuation. Infection \& Immunity, 55(11), 2802-2806.

21. Debrabant A, Nakhasi H. 2003. Programmed cell death in trypanosomatids: is it an altruistic mechanism for survival of the fittest? Kinetoplastid Biology \& Disease, 2(1), 7.

22. Djavaheri-Mergny M, Maiuri MC, Kroemer G. 2010. Cross talk between apoptosis and autophagy by caspase-mediated cleavage of Beclin 1. Oncogene, 29(12), 1717-1719.

23. Dotiwala F, Mulik S, Polidoro RB, Ansara JA, Burleigh BA, Walch M, Gazzinelli RT, Lieberman J. 2016. Killer lymphocytes use granulysin, perforin and granzymes to kill intracellular parasites. Nature Medicine, 22(2), 210-216.
24. Duszenko M, Figarella K, Macleod ET, Welburn SC. 2006. Death of a trypanosome: a selfish altruism. Trends in Parasitology, 22(11), 536-542.

25. El-Fadili AK, Zangger H, Desponds C, Gonzalez IJ, Zalila H, Schaff C, Ives A, Masina S, Mottram JC, Fasel N. 2010. Cathepsin B-like and cell death in the unicellular human pathogen Leishmania. Cell Death \& Disease, 1, e71.

26. Elmore S. 2007. Apoptosis: a review of programmed cell death. Toxicologic Pathology, 35(4), 495-516.

27. Ersfeld K, Barraclough H, Gull K. 2005. Evolutionary relationships and protein domain architecture in an expanded calpain superfamily in kinetoplastid parasites. Journal of Molecular Evolution, 61(6), 742-757.

28. Galluzzi L, Bravo-San Pedro JM, Vitale I, Aaronson SA, Abrams JM, Adam D, Alnemri ES, Altucci L, Andrews D, Annicchiarico-Petruzzelli M, Baehrecke EH, Bazan NG, Bertrand MJ, Bianchi K, Blagosklonny MV, Blomgren K, Borner C, Bredesen DE, Brenner C, Campanella M, Candi E, Cecconi F, Chan FK, Chandel NS, Cheng EH, Chipuk JE, Cidlowski JA, Ciechanover A, Dawson TM, Dawson VL, De Laurenzi V, De Maria R, Debatin K-M, Di Daniele N, Dixit VM, Dynlacht BD, El-Deiry WS, Fimia GM, Flavell RA, Fulda S, Garrido C, Gougeon M-L, Green DR, Gronemeyer H, Hajnoczky G, Hardwick JM, Hengartner MO, Ichijo H, Joseph B, Jost PJ, Kaufmann T, Kepp O, Klionsky DJ, Knight RA, Kumar S, Lemasters JJ, Levine B, Linkermann A, Lipton SA, Lockshin RA, López-Otín C, Lugli E, Madeo F, Malorni W, Marine J-C, Martin SJ, Martinou J-C, Medema JP, Meier P, Melino S, Mizushima N, Moll U, Muñoz-Pinedo C, Nuñez G, Oberst A, Panaretakis T, Penninger JM, Peter ME, Piacentini M, Pinton P, Prehn JH, Puthalakath H, Rabinovich GA, Ravichandran KS, Rizzuto R, Rodrigues CM, Rubinsztein DC, Rudel T, Shi Y, Simon H-U, Stockwell BR, Szabadkai G, Tait SW, Tang HL, Tavernarakis N, Tsujimoto Y, Vanden Berghe T, Vandenabeele P, Villunger A, Wagner EF, Walczak H, White E, Wood WG, Yuan J, Zakeri Z, Zhivotovsky B, Melino G, Kroemer G. 2015. Essential versus accessory aspects of cell death: recommendations of the NCCD 2015. Cell Death \& Differentiation, 22(1), 58-73.

29. Galluzzi L, Vitale I, Aaronson SA, Abrams JM, Adam D, Agostinis P, Alnemri ES, Altucci L, Amelio I, Andrews DW, Annicchiarico-Petruzzelli M, Antonov AV, Arama E, Baehrecke EH, Barlev NA, Bazan NG, Bernassola F, Bertrand MJM, Bianchi K, Blagosklonny MV, Blomgren K, Borner C, Boya P, Brenner C, Campanella M, Candi E, Carmona-Gutierrez D, Cecconi F, Chan FK-M, Chandel NS, Cheng EH, Chipuk JE, Cidlowski JA, Ciechanover A, Cohen GM, Conrad M, CubillosRuiz JR, Czabotar PE, D'Angiolella V, Dawson TM, Dawson VL, De Laurenzi V, De Maria R, Debatin K-M, DeBerardinis RJ, Deshmukh M, Di Daniele N, Di Virgilio F, Dixit VM, Dixon SJ, Duckett CS, Dynlacht BD, El-Deiry WS, Elrod JW, Fimia GM, Fulda S, García-Sáez AJ, Garg AD, Garrido C, Gavathiotis E, Golstein P, Gottlieb E, Green DR, Greene LA, Gronemeyer H, Gross A, Hajnoczky G, Hardwick JM, Harris IS, Hengartner MO, Hetz C, Ichijo H, Jäättelä M, Joseph B, Jost PJ, Juin PP, Kaiser WJ, Karin M, Kaufmann T, Kepp O, Kimchi A, Kitsis RN, Klionsky DJ, Knight RA, Kumar S, Lee SW, Lemasters JJ, Levine B, Linkermann A, Lipton SA, Lockshin RA, López-Otín C, Lowe SW, Luedde T, Lugli E, MacFarlane M, Madeo F, Malewicz M, Malorni W, Manic G, Marine J-C, Martin SJ, Martinou J-C, Medema JP, Mehlen P, Meier P, Melino S, Miao EA, Molkentin JD, Moll UM, Muñoz-Pinedo C, Nagata S, Nuñez G, Oberst A, Oren M, Overholtzer M, Pagano M, Panaretakis T, Pasparakis M, Penninger JM, Pereira DM, Pervaiz S, Peter ME, Piacentini M, Pinton P, Prehn JHM, Puthalakath H, Rabinovich GA, Rehm M, Rizzuto R, Rodrigues 
CMP, Rubinsztein DC, Rudel T, Ryan KM, Sayan E, Scorrano L, Shao F, Shi Y, Silke J, Simon H-U, Sistigu A, Stockwell BR, Strasser A, Szabadkai G, Tait SWG, Tang D, Tavernarakis N, Thorburn A, Tsujimoto Y, Turk B, Vanden Berghe $\mathrm{T}$, Vandenabeele P, Vander Heiden MG, Villunger A, Virgin HW, Vousden KH, Vucic D, Wagner EF, Walczak H, Wallach D, Wang Y, Wells JA, Wood W, Yuan J, Zakeri Z, Zhivotovsky B, Zitvogel L, Melino G, Kroemer G. 2018. Molecular mechanisms of cell death: recommendations of the Nomenclature Committee on Cell Death 2018. Cell Death \& Differentiation, 25(3), 486-541.

30. Galluzzi L, Vitale I, Abrams JM, Alnemri ES, Baehrecke EH, Blagosklonny MV, Dawson TM, Dawson VL, El-Deiry WS, Fulda S, Gottlieb E, Green DR, Hengartner MO, Kepp O, Knight RA, Kumar S, Lipton SA, Lu X, Madeo F, Malorni W, Mehlen P, Nuñez G, Peter ME, Piacentini M, Rubinsztein DC, Shi Y, Simon H-U, Vandenabeele P, White E, Yuan J, Zhivotovsky B, Melino G, Kroemer G. 2012. Molecular definitions of cell death subroutines: recommendations of the Nomenclature Committee on Cell Death 2012. Cell Death and Differentiation, 19(1), 107-120.

31. Gannavaram S, Vedvyas C, Debrabant A. 2008. Conservation of the pro-apoptotic nuclease activity of endonuclease $\mathrm{G}$ in unicellular trypanosomatid parasites. Journal of Cell Science, 121(1), 99-109.

32. Genes CM, de Lucio H, González VM, Sánchez-Murcia PA, Rico E, Gago F, Fasel N, Jiménez-Ruiz A. 2016. A functional BH3 domain in an aquaporin from Leishmania infantum. Cell Death Discovery, 2, 16043.

33. Genes CM, de Lucio H, Sánchez-Murcia PA, Gago F, JiménezRuiz A. 2016. Pro-death activity of a BH3 domain in an aquaporin from the protozoan parasite Leishmania. Cell Death \& Disease, 7(7), e2318-e2318.

34. Goll DE, Thompson VF, Li H, Wei W, Cong J. 2003. The calpain system. Physiological Reviews, 83(3), 731-801.

35. González IJ, Desponds C, Schaff C, Mottram JC, Fasel N. 2007. Leishmania major metacaspase can replace yeast metacaspase in programmed cell death and has arginine-specific cysteine peptidase activity. International Journal for Parasitology, 37(2), 161-172.

36. Holzmuller P, Sereno D, Cavaleyra M, Mangot I, Daulouede S, Vincendeau P, Lemesre J-L. 2002. Nitric oxide-mediated proteasome-dependent oligonucleosomal DNA fragmentation in Leishmania amazonensis amastigotes. Infection and Immunity, 70(7), 3727-3735.

37. Jeong H-S, Choi HY, Lee E-R, Kim J-H, Jeon K, Lee H-J, Cho S-G. 2011. Involvement of caspase-9 in autophagy-mediated cell survival pathway. Biochimica et Biophysica Acta, 1813(1), 80-90.

38. Jiménez-Ruiz A, Alzate JF, Macleod ET, Lüder CGK, Fasel N, Hurd H. 2010. Apoptotic markers in protozoan parasites. Parasites \& Vectors, 3, 104.

39. Kerr JF, Wyllie AH, Currie AR. 1972. Apoptosis: a basic biological phenomenon with wide-ranging implications in tissue kinetics. British Journal of Cancer, 26(4), 239-257.

40. Kroemer G, El-Deiry WS, Golstein P, Peter ME, Vaux D, Vandenabeele P, Zhivotovsky B, Blagosklonny MV, Malorni W, Knight RA, Piacentini M, Nagata S, Melino G. 2005. Classification of cell death: recommendations of the Nomenclature Committee on Cell Death. Cell Death \& Differentiation, 12(S2), 1463-1467.

41. Kroemer G, Galluzzi L, Vandenabeele P, Abrams J, Alnemri ES, Baehrecke EH, Blagosklonny MV, El-Deiry WS, Golstein P, Green DR, Hengartner M, Knight RA, Kumar S, Lipton SA, Malorni W, Nuñez G, Peter ME, Tschopp J, Yuan J, Piacentini M, Zhivotovsky B, Melino G, Nomenclature Committee on Cell
Death 2009. 2009. Classification of cell death: recommendations of the Nomenclature Committee on Cell Death 2009. Cell Death and Differentiation, 16(1), 3-11.

42. Lamkanfi M, Festjens N, Declercq W, Vanden Berghe T, Vandenabeele P. 2007. Caspases in cell survival, proliferation and differentiation. Cell Death \& Differentiation, 14(1), 44-55.

43. Lee N, Bertholet S, Debrabant A, Muller J, Duncan R, Nakhasi HL. 2002. Programmed cell death in the unicellular protozoan parasite Leishmania. Cell Death \& Differentiation, 9(1), 53-64.

44. Lee N, Gannavaram S, Selvapandiyan A, Debrabant A. 2007. Characterization of metacaspases with trypsin-like activity and their putative role in programmed cell death in the protozoan parasite Leishmania. Eukaryotic Cell, 6(10), 1745-1757.

45. Levine B, Klionsky DJ. 2004. Development by self-digestion: molecular mechanisms and biological functions of autophagy. Developmental Cell, 6(4), 463-477.

46. Li LY, Luo X, Wang X. 2001. Endonuclease G is an apoptotic DNase when released from mitochondria. Nature, 412(6842), 95-99.

47. Lüder CG, Campos-Salinas J, Gonzalez-Rey E, van Zandbergen G. 2010. Impact of protozoan cell death on parasite-host interactions and pathogenesis. Parasites \& Vectors, 3, 116.

48. Mariño G, Niso-Santano M, Baehrecke EH, Kroemer G. 2014. Self-consumption: the interplay of autophagy and apoptosis. Nature Reviews. Molecular Cell Biology, 15(2), 81-94.

49. Martin R, Gonzalez I, Fasel N. 2014. Leishmania metacaspase: an arginine-specific peptidase. Methods in Molecular Biology, $1133,189-202$.

50. Martin SJ. 1995. Early redistribution of plasma membrane phosphatidylserine is a general feature of apoptosis regardless of the initiating stimulus: inhibition by overexpression of Bcl-2 and Abl. Journal of Experimental Medicine, 182(5), 1545-1556.

51. McNicoll F, Drummelsmith J, Müller M, Madore É, Boilard N, Ouellette M, Papadopoulou B. 2006. A combined proteomic and transcriptomic approach to the study of stage differentiation in Leishmania infantum. Proteomics, 6(12), 3567-3581.

52. Meslin B, Beavogui AH, Fasel N, Picot S. 2011. Plasmodium falciparum metacaspase PfMCA-1 triggers a z-VAD-fmk inhibitable protease to promote cell death. PLoS One, 6(8), e23867.

53. Oliva C, Sánchez-Murcia PA, Rico E, Bravo A, Menéndez M, Gago F, Jiménez-Ruiz A. 2017. Structure-based domain assignment in Leishmania infantum EndoG: characterization of a $\mathrm{pH}$-dependent regulatory switch and a $\mathrm{C}$-terminal extension that largely dictates DNA substrate preferences. Nucleic Acids Research, 45(15), 9030-9045.

54. Padmanabhan PK, Samant M, Cloutier S, Simard MJ, Papadopoulou B. 2012. Apoptosis-like programmed cell death induces antisense ribosomal RNA (rRNA) fragmentation and rRNA degradation in Leishmania. Cell Death \& Differentiation, 19(12), 1972-1982.

55. Paris C, Loiseau PM, Bories C, Bréard J. 2004. Miltefosine induces apoptosis-like death in Leishmania donovani promastigotes. Antimicrobial Agents and Chemotherapy, 48(3), 852-859.

56. Parrish J, Li L, Klotz K, Ledwich D, Wang X, Xue D. 2001. Mitochondrial endonuclease $\mathrm{G}$ is important for apoptosis in C. elegans. Nature, 412(6842), 90-94.

57. Peña MS, Cabral GC, Fotoran WL, Perez KR, Stolf BS. 2017. Metacaspase-binding peptide inhibits heat shock-induced death in Leishmania (L.) amazonensis. Cell Death \& Disease, 8(3), e2645-e2645.

58. Perrin BJ, Huttenlocher A. 2002. Calpain. The International Journal of Biochemistry \& Cell Biology, 34(7), 722-725.

59. Proto WR, Coombs GH, Mottram JC. 2013. Cell death in parasitic protozoa: regulated or incidental? Nature Reviews Microbiology, 11(1), 58-66. 
60. Raina P, Kaur S. 2012. Knockdown of LdMC1 and Hsp70 by antisense oligonucleotides causes cell-cycle defects and programmed cell death in Leishmania donovani. Molecular and Cellular Biochemistry, 359(1-2), 135-149.

61. Rico E, Alzate JF, Arias AA, Moreno D, Clos J, Gago F, Moreno I, Domínguez M, Jiménez-Ruiz A. 2009. Leishmania infantum expresses a mitochondrial nuclease homologous to EndoG that migrates to the nucleus in response to an apoptotic stimulus. Molecular and Biochemical Parasitology, 163(1), 28-38.

62. Rico E, Oliva C, Gutierrez KJ, Alzate JF, Genes CM, Moreno D, Casanova E, Gigante A, Perez-Perez M-J, Camarasa M-J, Clos J, Gago F, Jimenez-Ruiz A. 2014. Leishmania infantum EndoG is an endo/exo-nuclease essential for parasite survival. PLoS One, 9(2), e89526.

63. Shaha C. 2006. Apoptosis in Leishmania species \& its relevance to disease pathogenesis. Indian Journal of Medical Research, 123(3), 233-244.

64. Smirlis D, Duszenko M, Ruiz AJ, Scoulica E, Bastien P, Fasel N, Soteriadou K. 2010. Targeting essential pathways in trypanosomatids gives insights into protozoan mechanisms of cell death. Parasites \& Vectors, 3, 107.

65. Tsiatsiani L, Van Breusegem F, Gallois P, Zavialov A, Lam E, Bozhkov PV. 2011. Metacaspases. Cell Death \& Differentiation, 18(8), 1279-1288.

66. van Loo G, Schotte P, van Gurp M, Demol H, Hoorelbeke B, Gevaert K, Rodriguez I, Ruiz-Carrillo A, Vandekerckhove J, Declercq W, Beyaert R, Vandenabeele P. 2001. Endonuclease $\mathrm{G}$ : a mitochondrial protein released in apoptosis and involved in caspase-independent DNA degradation. Cell Death \& Differentiation, 8(12), 1136-1142.

67. van Zandbergen G, Bollinger A, Wenzel A, Kamhawi S, Voll R, Klinger M, Müller A, Hölscher C, Herrmann M, Sacks D, Solbach W, Laskay T. 2006. Leishmania disease development depends on the presence of apoptotic promastigotes in the virulent inoculum. Proceedings of the National Academy of Sciences of the United States of America, 103(37), 13837-13842.

68. Vercammen D, Declercq W, Vandenabeele P, Van Breusegem F. 2007. Are metacaspases caspases? Journal of Cell Biology, 179(3), 375-380.

69. Vergnes B, Gourbal B, Girard I, Sundar S, Drummelsmith J, Ouellette M. 2007. A proteomics screen implicates HSP83 and a small kinetoplastid calpain-related protein in drug resistance in Leishmania donovani clinical field isolates by modulating druginduced programmed cell death. Molecular \& Cellular Proteomics, 6(1), 88-101.

70. Wanderley JLM, Pinto da Silva LH, Deolindo P, Soong L, Borges VM, Prates DB, de Souza APA, Barral A, Balanco JMdF, Nascimento MTCd, Saraiva EM, Barcinski MA. 2009. Cooperation between Apoptotic and Viable Metacyclics Enhances the Pathogenesis of Leishmaniasis. PLoS One, 4(5), e5733.

71. Weingärtner A, Kemmer G, Müller FD, Zampieri RA, Gonzaga dos Santos M, Schiller J, Pomorski TG. 2012. Leishmania promastigotes lack phosphatidylserine but bind annexin $\mathrm{V}$ upon permeabilization or miltefosine treatment. PLoS One, 7(8), e42070.

72. Welburn SC, Barcinski MA, Williams GT. 1997. Programmed cell death in trypanosomatids. Parasitology Today, 13(1), $22-26$.

73. Zalila H, González IJ, El-Fadili AK, Delgado MB, Desponds C, Schaff C, Fasel N. 2011. Processing of metacaspase into a cytoplasmic catalytic domain mediating cell death in Leishmania major. Molecular Microbiology, 79(1), 222-239.

74. Zangger H, Mottram JC, Fasel N. 2002. Cell death in Leishmania induced by stress and differentiation: programmed cell death or necrosis? Cell Death \& Differentiation, 9(10), $1126-1139$

Cite this article as: Basmaciyan L \& Casanova M. 2019. Cell death in Leishmania. Parasite 26, 71.

(0) PARASTE

An international open-access, peer-reviewed, online journal publishing high quality papers on all aspects of human and animal parasitology

Reviews, articles and short notes may be submitted. Fields include, but are not limited to: general, medical and veterinary parasitology; morphology, including ultrastructure; parasite systematics, including entomology, acarology, helminthology and protistology, and molecular analyses; molecular biology and biochemistry; immunology of parasitic diseases; host-parasite relationships; ecology and life history of parasites; epidemiology; therapeutics; new diagnostic tools.

All papers in Parasite are published in English. Manuscripts should have a broad interest and must not have been published or submitted elsewhere. No limit is imposed on the length of manuscripts.

Parasite (open-access) continues Parasite (print and online editions, 1994-2012) and Annales de Parasitologie Humaine et Comparée (1923-1993) and is the official journal of the Société Française de Parasitologie. 